\title{
圈 \\ The Game of the Sphere or of the Universe - a Spiral Race Game from 17TH CENTURY FRANCE
}

\author{
Adrian Seville \\ Emeritus Professor, City University, London
}

\begin{abstract}
Simple race games, played with dice and without choice of move, are known from antiquity. In the late 16th century, specific examples of this class of game emerged from Italy and spread rapidly into other countries of Europe. Pre-eminent was the Game of the Goose, which spawned thousands of variants over the succeeding centuries to the present day, including educational, polemical and promotional variants 1

The educational variants began as a French invention of the 17th century, the earliest of known date being a game to teach Geography, the Jeu du Monde by Pierre Duval, published in 1645. By the end of the century, games designed to teach several of the other accomplishments required of the noble cadet class had been developed: History, the Arts of War, and Heraldry being notable among them.

A remarkable example of a game within this class is the astronomical game, Le Jeu de la Sphere ou de l'Univers selon Tycho Brahe, published in 1661 by E(s)tienne Vouillemont in Paris. The present paper analyses this game in detail, showing how it combines four kinds of knowledge systems: natural philosophy, based on the Ptolemaic sphere; biblical knowledge; astrology, with planetary and zodiacal influences; and classical knowledge embodied in the names of the constellations. The game not only presents all four on an equal footing but also explores links between them, indicating some acceptance of an overall knowledge-system. Despite the title, there is no evidence of the Tychonian scheme for planetary motion, nor of any Copernican or Galilean influence.

This game is to be contrasted with medieval race games, based on numerology and symbolism, and with race games towards the end of the Early Modern period in which science is fully accepted.
\end{abstract}

\footnotetext{
${ }^{1}$ Adrian Seville. The Royal Game of the Goose. New York: The Grolier Club, 2016
} 


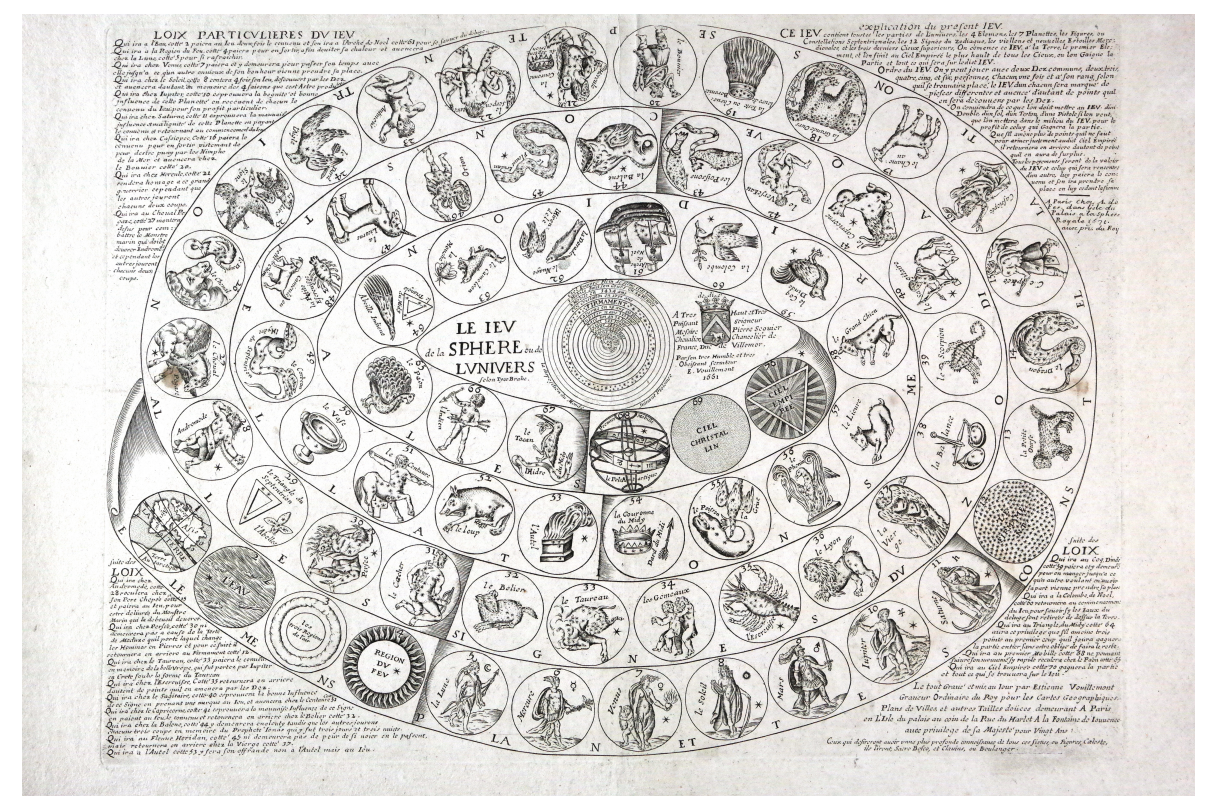

Figure 1: The Game of the Sphere or of the Universe. Paris: E. Vouillemont, 1661, reprint A de Fer. 1671 (author's collection).

\section{The Game of the Universe}

The example of the game shown in Figure 1 is in the present author's collection. The engraved game sheet is of large format $(38 \times 53 \mathrm{~cm}$ to the plate mark) and bears in the centre a dedication to the Duc de Villemor ${ }^{2}$ signed E Vouillemont and dated 1661. However, this example, like the example in the Bibliothque nationale de France, has an addition in the upper right corner, giving the imprint of A[ntoine] de Fer at the Sphere Royale in Paris, with the date of 1671, but the example reproduced by Girard and Quéte 3 does not, indicating that it is from the first publication by Vouillemont in 1661 .

In the lower right corner, Vouillemont also claims authorship as follows: 'Le tout Gravé et mis au jour par Estienne Vouillemont Graveur Ordinaire du Roy, pour les Cartes Geographiques et Plans de Villes et autres Tailles douces'. [All engraved and published by Estienne Vouillemont, engraver in the service of the King for geographical maps and town plans and other

\footnotetext{
${ }^{2}$ Pierre Séguier 1588-1672, Chancellor of France from 1635.

${ }^{3}$ Alain R. Girard and Claude Quétel. L'histoire de France racontée par le Jeu de l'Oie. Paris: Balland/Massin, 1982, plate 36.
} 
copper engravings]. He is also noteworthy for having produced in 1659 Duval's Jeu de France, which, like Duval's earlier Jeu du monde, has the 63 spaces associated with Goose; however, the Universe game ends at space 70 and has no connection with the numerology of Goose. Nevertheless, all these games 4 share with Goose the typical inward spiral track and the basic rules, though they do not have a regular sequence of goose-like favourable spaces.

\section{The playing track}

The 'explanation' of the game in the upper right corner says that it contains the four elements, the seven planets, the figures of the Northern constellations, the twelve signs of the zodiac, the old and new Southern stars and the three last 'upper heavens'. Some details of the track, taken from the example reproduced by Girard and Quétel, are shown in Figure 2a.

The track begins with the four elements: Earth, Water, Air, and Fire, in a band labelled 'ELEMENS'. Then come the heavenly bodies: Moon, Mercury, Venus, Sun, Mars, Jupiter, Saturn in order of their periods of apparent rotation round the Earth, in a band labelled 'PLANETTES' [sic].

Next are the stars, first as the Firmament at space 12, then 19 spaces featuring the Northern constellations; next, the 12 Zodiacal constellations; and finally 24 spaces for the Southern constellations. Several spaces show two or even three constellations. The total of 69 constellations is to be compared with the 46 in the full edition of Tycho's Star Atlas, which however did not include the four southernmost constellations of Ptolemy's Almagest, namely Lupus, Ara, Corona Australis and Piscis Austrinus. All of Ptolemy's constellations are included in the game, though Serpens is included only by implication, in the figure of Serpentarius (now Ophiuchus) at space 22. The additional constellations are some but not all of those attributed to Petrus Plancius. The Magellanic Cloud is also included. It is not known what source or sources Vouillemont used in compiling his list of constellations, many now obsolete, nor what was the source of his iconography. Table 1 lists the constellations as inscribed on the game, with their Latin equivalents.

The last three spaces of the track represent the primum mobile, the Crystalline Heaven and (the winning space) the Empyrean Heaven.

\footnotetext{
${ }^{4} \mathrm{~A}$ re-engraved version of the Universe game, in Portuguese language, is in the Biblioteca Pública de Évora, dedicated to the Sereníssimo Príncipe do Brazil.
}

Board Game Studies Journal 10, pp. 1-16 DOI $10.1515 /$ bgs-2016-0001 

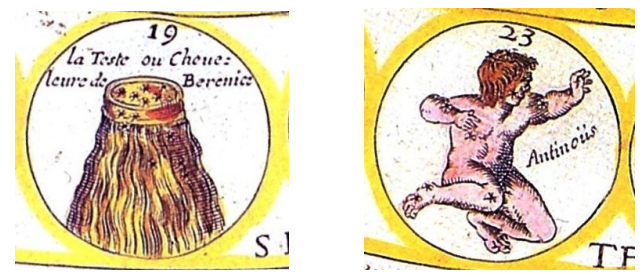

Figure 2a: The Northern Constellations depicted in the game were all recorded by Ptolemy except for two: Coma Berenices (19) and the now-defunct constellation Antinous (23). They are considered to be the first post-Ptolemaic constellations to be depicted on a celestial globe. Both were recorded by Tycho Brahe in 1602 .

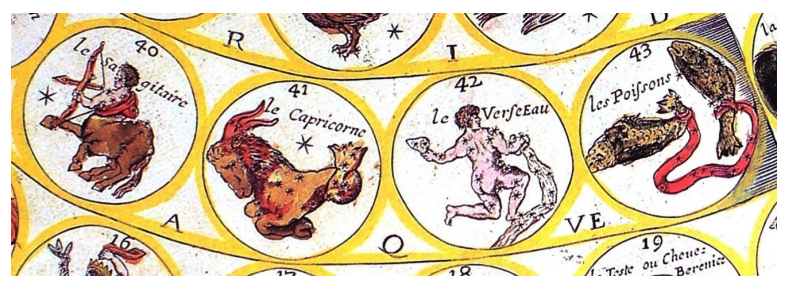

Figure 2b: The Zodiacal Constellations were all recorded by Ptolemy.

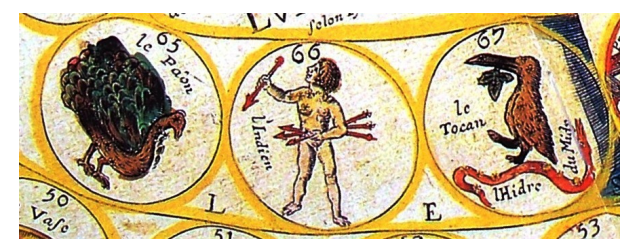

Figure 2c: The Southern Constellations depicted in the game include all of Ptolemy's constellations together with some of the additional constellations introduced by Petrus Plancius up to 1612/1613. These include the obsolete examples shown here: the Peacock, the Indian, the Toucan and the Southern Hydra.

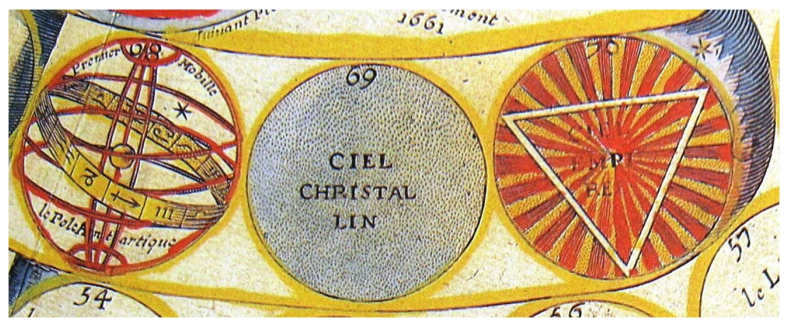

Figure 2d: The end of the track shows the Primum Mobile, the Crystalline Heaven, and the Empyrean Heaven (the winning space, marked with the sign of the Trinity). 


\section{The Sphere at the centre of the game}

In the centre of the game is depicted a multi-layered sphere (Figure 3) labelled (in French): the arrangement of the World according to Ptolemy' showing the Earth at the centre. Between the Earth and the spheres of the heavenly bodies, each labelled with its period of apparent rotation in days, is a three-layered model of the atmosphere (see next section).

On the outside are the spheres of the heavens. The outermost is the Empyrean Heaven, inscribed 'full of glory and of light' and regarded as the abode of God and the Elect. Next comes the Primum Mobile5, inscribed: '1 Mobile faict son cours en 24 Heures', then the Secundum Mobile inscribed '2 mobile en 3434 ans', then the Crystalline Heaven, in reference to the 'waters... above the firmament' in Genesis 1:7, and inscribed 'ciel cristallin en 1717 ans'. Finally, there is the Firmament of the fixed stars.

The Ptolemaic sphere is further discussed below.

\section{The three-layer model of the atmosphere}

The three-layer model of the atmosphere is shown at space 3, labelled 'the three regions of the air'. This was a standard model in the Natural Philosophy of the time ${ }^{6}$.

[The Aire] is deuided of the naturall Philosophers into three Regions, that is to say, the highest Region, the Middle Region, and the lowest Region, which highest Region being turned about by the fire, is thereby made the hotter, wherein all fierie impressions are bredde, as lightnings, fire drakes, blazing starres and such like.

The middle Region is extreame cold by contra opposition by reason that it is placed in the midst betwixt two hotte Regions, and therefore in this Region are bred all cold watry impressions, as frost, snow, ice, haile, and such like.

The lowest Region is hotte by the reflexe of the sunne, whose beames first striking the earth, doe rebound backe againe to that Region, wherein are bred cloudes, dewes, raynes, and such like moderate watry impressions.

\footnotetext{
${ }^{5}$ The Primum Mobile was the fastest-moving of the spheres and was held to be the driver for the 24-hour rotation of the heavens with respect to the Earth.

${ }^{6}$ Blundevile's Exercises, fol. 179 b, ed. 1594.
} 


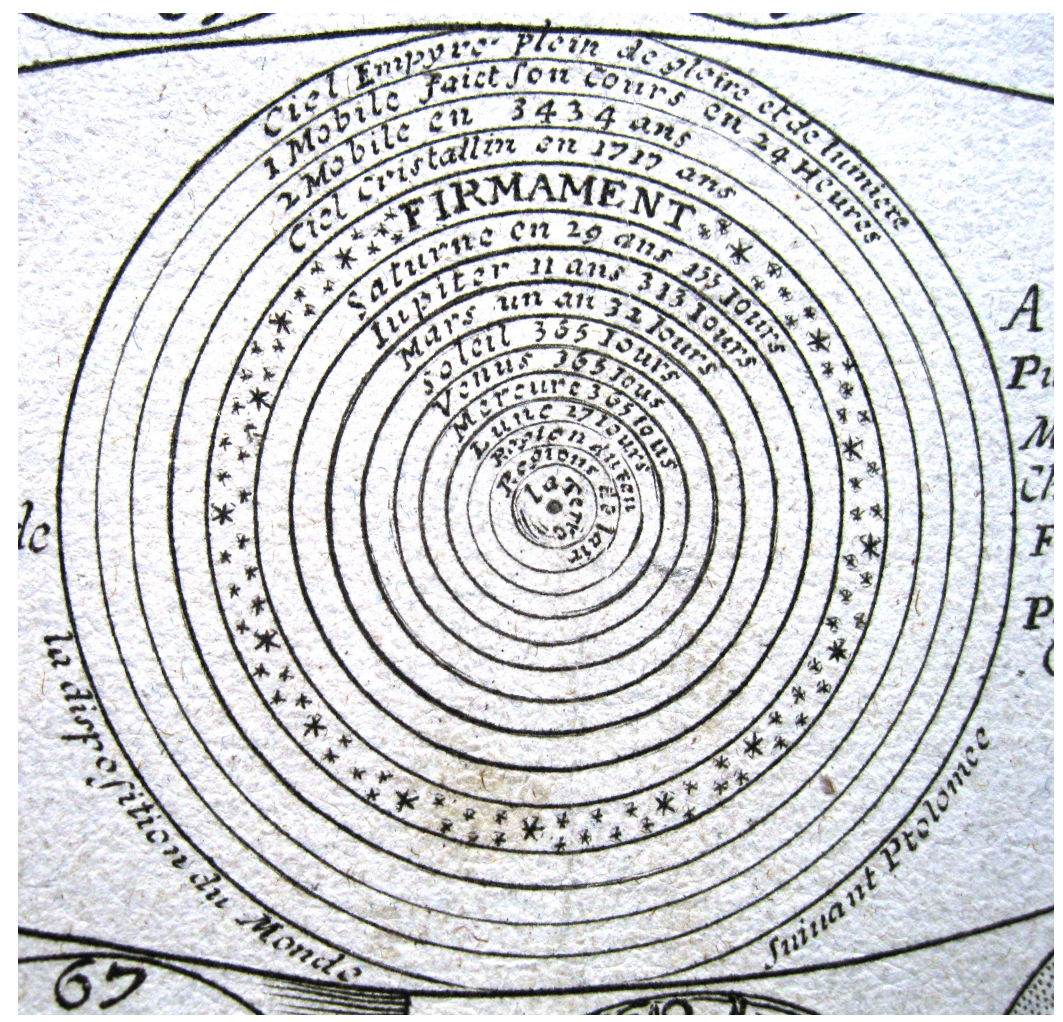

Figure 3: The central sphere of the Universe game.

Figure 4 shows such a model in a typical diagrammatic form 7 .

\section{The rules of the game}

The rules of the game are inscribed in the four corners of the game, set out below in a free translation 8 . At the top right are the general laws for playing the game. The rules for particular spaces are in the remaining corners: in what follows, these have been grouped according to the kind of knowledge involved.

\footnotetext{
${ }^{7}$ Antoninus Saliba. The Elements, c. 1600, Rothschild (National Trust) Collection, Waddesdon Manor.

${ }^{8}$ In http://www.giochidelloca.it/scheda.php?id=199 there is a transcription in the original French spelling
} 


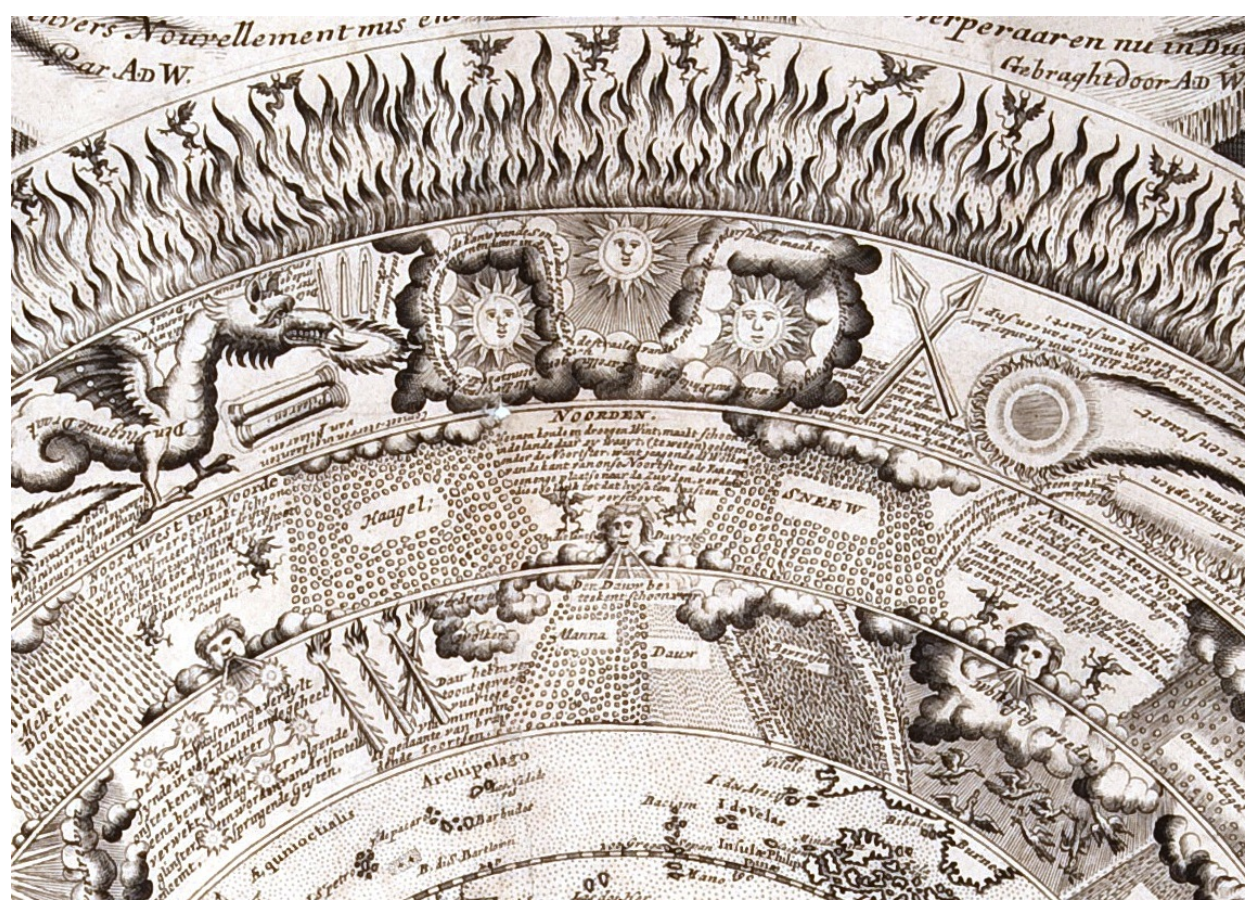

Figure 4: Detail of Antoninus Saliba's Veritable Representation des Premieres Matieres ou Elements. Holland: Ambrose Schevenhuyse, c. 1600 (Rothschild Collection, Waddesdon - National Trust).

\section{General laws}

The game is 'from the Earth to the Empyrean Heaven', on reaching which the player wins the game and all the [stakes] placed on it. The game is played with two ordinary dice, by two, three, four, five or six players.

They throw in turn for start and each has a marker which is advanced according to the throw. The game is to be played for agreed stakes of 'a double, a sol, a teston or a pistole 9 . Initially, each player puts one stake in the middle of the game for the profit of the winner. To win, the player must reach the Empyrean Heaven exactly — excess points are counted backwards. All payments to the game are of the same value as the agreed stake. If a player is hit by another, he pays the agreed stake and they change places.

These General Laws are entirely consistent with the Game of the Goose.

\footnotetext{
${ }^{9}$ The double was a copper coin; the sol was of brass; the silver teston was worth ten sols and the gold pistole was worth about 200 sols - a wide range of stakes, therefore.
} 


\section{Rules involving Biblical knowledge}

Space 2, Water: pay two stakes and go to Noah's Ark, space 61, to save yourself from the flood.

Space 44, the Whale: remain there swallowed while the others play three throws, in memory of the Prophet Jonah, who was there for three days and three nights.

Space 53, the Altar (Ara): pay your offering to the Game not to the Altar. Space 60, the Dove of Noah (Columba): go back to the start of the game to discover whether the waters of the Deluge have retreated from the face of the Earth.

Space 70, the Empyrean Heaven: you win the game, taking all [the stakes] to be found on the game.

\section{Rules involving astrological symbolism}

Space 4, Fire: pay to avoid its heat by advancing to the Moon, space 5, to refresh yourself.

Space 7, Venus: pay, to spend time with her until another, envious of your happiness, arrives to take your place. [This parallels the rule in Goose for the hazards of the Well and the Prison].

Space 10, Jupiter: experience the benignity and good influence of this planet by receiving one stake from each player for your own profit.

Space 11, Saturn: experience the malignity and bad influence of this planet by paying the stake and returning to the start. [This parallels the rule in Goose for the Death hazard].

Space 40, Sagittarius: experience the good effect of this Sign, taking a stake from the game and advancing to the Centaur (space 51). [Sagittarius is commonly represented as a centaur drawing a bow, as here].

Space 41, Capricorn: experience the bad influence of this Sign by paying a stake and returning to the Ram (space 32 ).

\section{Rules involving Classical Mythology}

Space 16, Cassiopeia: pay a stake and leave quickly for fear of being punished by the Sea Nymph, [She was placed in the sky as a punishment for her boast that she and her daughter Andromeda were more beautiful than the sea nymphs] Advance to the 'bouvier' (Botes space 20). [There is doubt as to who this figure represents. He may represent the herdsman who led the seven oxen to the constellation of the plough, or he may be the inventor of

Board Game Studies Journal 10, pp. 1-16 DOI $10.1515 /$ bgs-2016-0001 
the plough itself. In either case, the link is presumably that Cassiopeia is opposite in the sky to the Plough].

Space 21, Hercules: render homage to this great warrior by staying until the others have each played two turns. [This is similar to the rule for the Inn hazard in Goose].

Space 27, Pegasus: mount him to fight the Sea Monster which is about to devour Andromeda.

Space 28, Andromeda: pay a stake and go back to her father Cepheus (space 15) to be delivered from the Sea Monster which is about to devour her; meanwhile the others play two throws.

Space 30, Perseus: you cannot stay because of the head of Medusa that he carries which turns men to stone; hence go back to the Firmament (space 12).

Space 33, Taurus (the Bull): pay in memory of the beautiful Europa who was carried to Crete by Jupiter in the form of a Bull.

Space 35, Cancer [represented as a Crayfish]: return according to the points shown on the dice. [In Greek mythology, Cancer is identified with the crab that appeared while Hercules was fighting the many-headed Hydra.].

Space 45, River Heridan [Eridanus, the Ancient Greek name for the River Po]: you must not stay for fear of being drowned but must return to the Virgin (Virgo, space 37). [The connection with the Virgin is not clear: Eridanus is normally associated with the Phaeton myth].

\section{Rules involving Natural Philosophy}

Space 8, the Sun: advance by four times the throw on your dice, in recognition of the four seasons that this star produces.

Space 68, the Primum Mobile: not being able to keep up with such rapid motion, go back to the Peacock, space 65. [The rings on the peacock's tail classically represent the stars of the Firmament].

\section{Rules not involving a specific knowledge system}

Space 59, the Turkey-Cock (Coq D'Inde): pay, and wait to eat of it until another wanting his share comes to take your place.

Space 64, the Southern Triangle: if you throw three points at the first throw, you will have the privilege of winning the Game at once, without doing the rest.

Board Game Studies Journal 10, pp. 1-16 DOI $10.1515 /$ bgs-2016-0001 


\section{The combination of knowledge systems in the Uni- verse game}

The combination of knowledge systems evident in these rules is intriguing: Biblical knowledge, Astrology, Classical Mythology and Natural Philosophy all have equal place with the common-sense desire to share in eating a turkey! There is a high degree of logical connection within rules: the moves and penalties are not arbitrary but reflect the symbolic meaning of the space concerned.

Mostly, each rule operates within one of these knowledge systems - but the rule at Space 68 regarding the Primum Mobile combines ideas from two systems. The idea of failure to keep up with the rapid motion of this sphere comes from the geocentric model in which the sphere is responsible for the 24-hour rotations apparent from a 'stationary' Earth. But the consequence of this failure is going back to the Peacock, which symbolically represents the stars of the Firmament, in Greek myth.

\section{Discussion}

\section{Vouillemont's suggestions for further reading}

The only definite clues we have to Vouillemont's sources are the suggestions for further reading that end the text on the game sheet: 'Sacro Bosco, and Clavius, or Boulanger'.

Johannes de Sacrobosco (c. 1195 - c. 1256) was a scholar, monk and astronomer who taught at the University of Paris. His contribution to astronomy is the Tractatus de Sphaera (On the Sphere of the World) issued in 1230, where he describes the Ptolemaic universe. This was an influential book for several centuries and was standard knowledge for educated persons interested in astronomy even in Vouillemont's time.

Christopher Clavius (1538 - 1612) was a highly respected German Jesuit mathematician and astronomer, noted for his work on the calendar and whose text books on astronomy remained influential long after his death, even though he was a firm exponent of the geocentric system.

The third reference is presumably to Jean Boulanger's Traité de la sphere et son usage, which from the title would appear to be a work mainly about the use of the terrestrial globe.

It seems clear, if these sources are representative, that Vouillemont's world view was strictly geocentric.

Board Game Studies Journal 10, pp. 1-16 DOI $10.1515 /$ bgs-2016-0001 


\section{The scientific context of the Universe game}

It is instructive to compare the dates of various astronomers with the date of the Universe game, 1661: Ptolemy AD 90-168; Tycho Brahe 1546-1601, Copernicus 1473-1543, Galileo 1564-1642. Yet, the influence of Copernicus and Galileo is wholly absent. The game is firmly geocentric. Not until 1686 was the heliocentric system brought to popular attention in France by Bernard le Bovier de Fontenelle's Entretiens sur la pluralité des mondes.

How far is the game 'according to Tycho Brahe'? Tycho advocated a geo-heliocentric system in which the five then known planets orbit the sun, while the sun and the moon orbit the earth. This model, while not requiring the massive Earth to rotate, dealt with some of the problems later emphasized by Galileo's telescope, such as the plain fact that Venus orbits the sun.

There is no positive evidence on the face of the game that the Tychonic system was in the designer's contemplation. The negative evidence is the prominence given to the spherical geocentric model, labelled 'la disposition du Monde suivant Ptolomee'. This 'arrangement' is itself a medieval construct ${ }^{10}$, rather than something taken directly from Ptolemy, who dealt with each planet separately, rather than assembling their spheres into a unified 'system'. An example of such a system is that shown in Figure 5, from Peter Apian's Cosmographia, published in Antwerp in 1524. Its spheres correspond closely to those depicted in the centre of the game: three layers corresponding to the Earth and its atmosphere, then Moon, Mercury, Venus, Sun, Mars, Jupiter and Saturn. The eighth 'heaven' contains the Firmamentu[m], the ninth the Cristallinum. The tenth is the Primu[m] Mobile and outside of all is the COELVM EMPIREVM HABITACVLVM DEI ET OMNIVM ELECTORVM [the Empyrean heaven, Abode of God and all the Elect]. However, in the Universe game, an additional sphere, the '2 mobile' comes between the Cristallinum and the Primum Mobile.

The 'Secundum Mobile' was certainly a term familiar to Tycho Brahe, though he regarded it as a domain extending from the Earth as far as Saturn, rather than as a distinct 'onion skin' layer. He describes it thus 11 .

the space of the Secundum Mobile [extends] as far as the extreme distance of Saturn from the Earth. In this enormously

\footnotetext{
${ }^{10}$ Norwood Russell Hanson. Constellations and Conjectures. Dordrecht/Boston: D Reidel, 1973, p. 145.

${ }^{11}$ Brahe, Tycho. "Of the Discovery of the Place of Space...", Nature and Nature?s Laws, M. Hall, ed. New York: Walker \& Co, 1970. Original translation by A. Rupert and Marie Boas Hall.
}

Board Game Studies Journal 10, pp. 1-16 DOI 10.1515/bgs-2016-0001 
vast interval, seven planets perform incessantly their wonderful and almost divine periodic motions; so that I can say nothing about that immense distance of the Eighth Sphere, which is beyond doubt greater by far than that of Saturn at his furthest point.

It is apparent that Vouillemont did not derive his conception of the Secundum Mobile from Tycho Brahe.

A likely source for Vouillemont's sphere can however be found elsewhere: in the 1653 edition of Boisseur's Tresor des Cartes Geographique ${ }^{12}$, in which Sphere 9 having a period of 1717 years corrects for the supposed 'trepidation' of the precession of the ecliptic13, while Sphere 10 having a period of 3434 years corrects for the changing obliquity of the ecliptic.

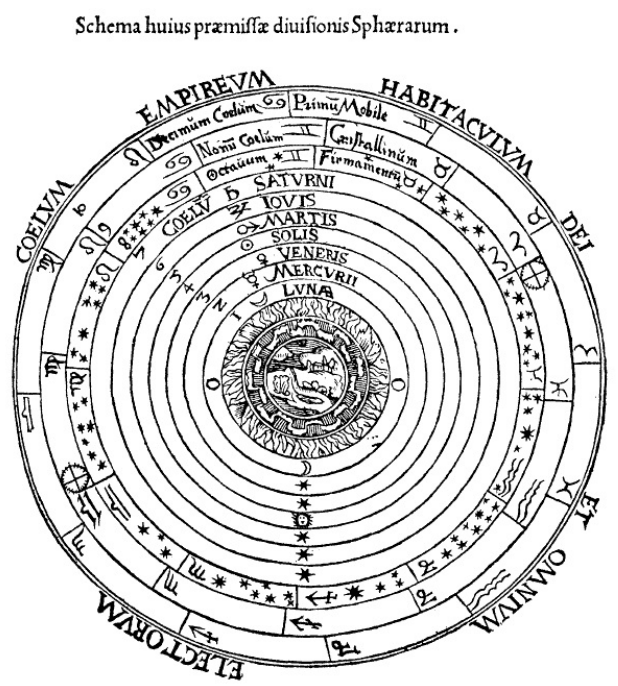

Figure 5: Detail of Antoninus Saliba's Veritable Representation des Premieres Matieres ou Elements. Holland: Ambrose Schevenhuyse, c. 1600 (Rothschild Collection, Waddesdon - National Trust).

\footnotetext{
${ }^{12}$ Illustrated in: Nick Kanas. Solar System Maps: From Antiquity to the Space Age. Springer, 2013. p. 12.

${ }^{13}$ It was erroneously supposed that the precession was not uniform but proceeded in a halting or hesitating manner: this supposition was based on faulty interpretation of observations from the time of Copernicus.
}

Board Game Studies Journal 10, pp. 1-16 DOI 10.1515/bgs-2016-0001 


\section{The connection with Pierre Duval}

Nothing is known about Vouillement beyond the bare information, inscribed on his engravings, that he was a map engraver in the King's service, with the royal privilege granted in 1639. The BnF lists between 20 and 30 of his maps and plans, not of direct interest here. However, as well as the Universe game, he also published Pierre Duval's Jeu de Franc£.

Duval was one of the premier map makers of Paris, an innovative specialist in educational atlases and the producer of several other educational games. His Jeu de France is very like the Universe game, which it pre-dates by just two years. Its track is made up of small circles, each containing a small map of a French province; the general rules are the same; and the appearance and layout are similar, though it has at its centre a key map of France instead of the central sphere of the Universe game.

The special rules for the individual hazards are topical, down-to-earth and often humorous. For example, at space 6, Ponthieu: take the stagecoach and go to the Isle de France to carry news to Paris of the progress of the King's armies [a reference to the Franco-Spanish wars]. At space 13, Brittany: having made a debauch in Nantes with the Bretons, embark for Bourdeaux in Guienne, 44, and pay. [The Bretons have been associated with the consumption of mead since the sixth century!] At space 58, Provence: at Marseilles with the intention of voyaging to Italy but will be taken by the Corsairs of Algiers and will pay a ransom to continue the game

This game provides a template with which to approach the intellectual content of the Universe game.

\section{The intellectual content of the Universe game}

However competent and innovative map makers such as Duval may have been, they were not specialist astronomers, cosmographers or indeed philosophers, so deep knowledge is not to be expected, especially in a product designed for education rather than scholarship. The Universe game is therefore best considered as the product of an educated man whose profession was map engraving, rather than someone with deep insight. Nonetheless, or indeed because of that, the attitude of mind that it reveals is intriguing.

As detailed above, the presence in the rules of Biblical knowledge, As-

\footnotetext{
${ }^{14}$ Adrian Seville. Le Jeu de France - Pierre Duval's Map Game. Brussels International Map Collectors Circle, Newsletter No. 21, January 2005: pp. 24-26. Online at http://www.giochidelloca.it/storia/BIMCC_2005.pdf
} 
trology, Classical Mythology and Natural Philosophy - as well as commonsense - suggests that Vouillemont regarded all these strands as of importance in the understanding of the heavens. He gives no particular prominence to any one strand.

Instead, the logical connections between one space and another are highlighted in a way that piques the imagination and aids the memory in later recall. Indeed, this feature of thematic spiral race games is the key to their continuing usefulness as educational tools.

Of these logical connections, the rule for the Primum Mobile [not being able to keep up with such rapid motion, go back to the Peacock, space $65]$ is the most striking, revealing a knowledge of Natural Philosophy that would not have been common, and indicating a willingness to combine this with classical mythology in a way that is both amusing and compelling even today.

The Biblical references are treated with no special reverence, though certainly without disrespect. The most overt sense of religion comes from the structuring of the game as leading 'from the Earth to the Empyrean heaven'; with the underlying idea of progress of the soul that illuminates the parent Goose game. Perhaps a sub-title for the game could be: a plain man's guide to the heavens!

Board Game Studies Journal 10, pp. 1-16 DOI $10.1515 /$ bgs-2016-0001 


\begin{tabular}{|c|c|c|c|}
\hline Space & Constellation & Latin & Origin \\
\hline & Northern & & \\
\hline 13 & la Petite Ourse & Ursa Minor & $\mathrm{PT}$ \\
\hline 14 & le Dragon & Draco & $\overline{\mathrm{PT}}$ \\
\hline 15 & Cephée & Cepheus & $\mathrm{PT}$ \\
\hline 16 & Cassiopée & Cassiopeia & PT \\
\hline 17 & le Chameau & Camelopardalis & $\mathrm{PL}$ \\
\hline 18 & le Grand Ours & Ursa Major & $\mathrm{PT}$ \\
\hline 19 & La Teste au Cheveleure de Berenice & Coma Berenices & TB \\
\hline 20 & Le Bouvier & Botes & PT \\
\hline \multirow[t]{2}{*}{21} & Hercule & Hercules & $\mathrm{PT}$ \\
\hline & la Couronne du Septentrion & Corona Borealis & $\overline{\mathrm{PT}}$ \\
\hline 22 & le Serpentaire & $\begin{array}{l}\text { Serpentarius } \\
\text { now Ophiuchus }\end{array}$ & $\mathrm{PT}$ \\
\hline 23 & Antinois & Antinous & TB \\
\hline \multirow{2}{*}{24} & le Dard & Sagitta & $\mathrm{PT}$ \\
\hline & l'Aigle & Aquila & PT \\
\hline \multirow{2}{*}{25} & la Liré & Lyra & $\mathrm{PT}$ \\
\hline & le signe & Cygnus & PT \\
\hline \multirow[t]{2}{*}{26} & le Dauphin & Delphinus & $\mathrm{PT}$ \\
\hline & le Cheval & Equuleus & PT \\
\hline 27 & le Cheval Pegase & Pegasus & $\mathrm{PT}$ \\
\hline 28 & Andromede & Andromeda & $\mathrm{PT}$ \\
\hline \multirow[t]{2}{*}{29} & le Triangle du Septentrion & Triangulum & PT \\
\hline & l'Abelles & Musca Borealis (ex. Apes) & PL \\
\hline 30 & Persée & Perseus & $\mathrm{PT}$ \\
\hline \multirow[t]{2}{*}{31} & le Cacher (mis-written for Cocher) & Auriga & $\mathrm{PT}$ \\
\hline & Zodiacal & & \\
\hline 32 & le Belier & Aries & PT \\
\hline 33 & le Taureau & Taurus & PT \\
\hline 34 & les Gemeaux & Gemini & $\mathrm{PT}$ \\
\hline 35 & l'Escreuisse & Cancer & $\mathrm{PT}$ \\
\hline 36 & le Lyon & Leo & $\mathrm{PT}$ \\
\hline 37 & la Vierge & Virgo & $\mathrm{PT}$ \\
\hline 38 & la Balance & Libra & $\mathrm{PT}$ \\
\hline 39 & le Scorpion & Scorpius & $\mathrm{PT}$ \\
\hline 40 & le Sagitaire & Sagittarius & $\mathrm{PT}$ \\
\hline 41 & le Capricorne & Capricornus & PT \\
\hline 42 & le VerseEau & Aquarius & $\mathrm{PT}$ \\
\hline 43 & les Poissons & Pisces & $\mathrm{PT}$ \\
\hline
\end{tabular}

LEGEND: PR Ptolomey PL Petrus Plancius TB Tycho Brahe

Table 1 (Part a) 


\begin{tabular}{|c|c|c|c|}
\hline Space & Constellation & Latin & Origin \\
\hline & Southern & & \\
\hline & & & \\
\hline 44 & la Balene & Cetus & $\mathrm{PT}$ \\
\hline 45 & le Fleuve Eridan & Eridanus & $\mathrm{PT}$ \\
\hline 46 & Orion & Orion & $\mathrm{PT}$ \\
\hline 47 & la Licorne & Monoceros & $\mathrm{PL}$ \\
\hline \multirow[t]{2}{*}{48} & la Petite Escreuisse & Cancer Minor & $\mathrm{PL}$ \\
\hline & Canucule ou petit Chien & Canis Minor & $\mathrm{PT}$ \\
\hline \multirow[t]{2}{*}{49} & l'Hydre du Septentrion & Hydra & $\mathrm{PT}$ \\
\hline & le Corbeau & Corvus & $\mathrm{PT}$ \\
\hline 50 & le Vase & Crater & $\mathrm{PT}$ \\
\hline 51 & le Centaure & Centaurus & $\mathrm{PT}$ \\
\hline 52 & le loup & Lupus & $\mathrm{PT}$ \\
\hline 53 & l'Autel & Ara & $\mathrm{PT}$ \\
\hline \multirow[t]{2}{*}{54} & la Couronne du Midy & Corona Australis & $\mathrm{PT}$ \\
\hline & Dard du Midi & Sagitta Australe & $\mathrm{PL}$ \\
\hline \multirow[t]{2}{*}{55} & le Poisson & Piscis Austrinus & $\mathrm{PT}$ \\
\hline & la Grue & Grus & $\mathrm{PL}$ \\
\hline 56 & le Phenix & Phoenix & $\mathrm{PL}$ \\
\hline 57 & le Lievre & Lepus & $\mathrm{PT}$ \\
\hline 58 & le Grand Chien & Canis Major & $\mathrm{PT}$ \\
\hline 59 & le Coq Dinde & Gallus & $\mathrm{PL}$ \\
\hline 60 & la Colombe & Columba (C. Noachi) & $\mathrm{PL}$ \\
\hline 61 & l'Arche de Noel (correctly Noé) & Argo Navis & $\mathrm{PT}$ \\
\hline \multirow[t]{3}{*}{62} & la Dorade & Dorado & $\mathrm{PL}$ \\
\hline & le Nuage & Large Magellanic Cloud & \\
\hline & l'Hirondele & Reticulum & \\
\hline \multirow[t]{2}{*}{63} & le Cameleon & Chamaeleon & $\mathrm{PL}$ \\
\hline & la Mouche & Musca (ex. Apis) & $\mathrm{PL}$ \\
\hline \multirow[t]{2}{*}{64} & le Triangle du Midy & Triangulum Australe & $\mathrm{PL}$ \\
\hline & Abeille Indiene & Apus & PL \\
\hline 65 & le Paon & Pavo & $\mathrm{PL}$ \\
\hline 66 & l'Indien & Indus & $\mathrm{PL}$ \\
\hline \multirow[t]{2}{*}{67} & le Tocan & Tucana & $\mathrm{PL}$ \\
\hline & l'Hidre du Midy & Hydrus & $\mathrm{PL}$ \\
\hline
\end{tabular}

LEGEND: PR Ptolomey PL Petrus Plancius TB Tycho Brahe

Table 1 (Part b) 